\title{
ANALIZA DRGAŃ WŁASNYCH PRZEKŁADNI ZĘBATEJ MAŁEJ MOCY
}

\begin{abstract}
W artykule omówiono drgania własne przekładni zębatej małej mocy, dedykowanej do współpracy z pompą hydrauliczną stoiska hamownianego. W procesie analizy wykorzystano metodę elementów skończonych i komercyjne oprogramowanie ANSYS. Analizę drgań omawianego układu prowadzono dwuetapowo. W pierwszej kolejności wyznaczono częstości własne drgań poprzecznych kół zębatych z uwzględnieniem rotacji kół. Następnie, wykorzystując opracowane wykresy Campbella, wyznaczono prędkości wzbudzenia poszczególnych częstości drgań własnych poprzecznych omawianych kół. W dalszej kolejności analizowano drgania własne korpusu reduktora. Rozważono dwa przypadki obliczeniowe. W pierwszym przypadku uwzględniono tylko masę i geometrię korpusu zasadniczego i pokrywy. W drugim przypadku uwzględniono dodatkowo masę poszczególnych kół oraz ich geometryczny rozkład. Na podstawie opracowanych modeli numerycznych wyznaczono pierwszych dziesięć częstości drgań własnych i odpowiadające im formy własne korpusu reduktora. Następnie wyniki te wykorzystano do oszacowania poziomu naprężeń $w$ ściankach korpusu dla dopuszczalnej wartości przyspieszenia. Prezentowana w pracy metodyka może być pomocna inżynierom zajmującym się analizą drgań przekładni zębatych.
\end{abstract}

Słowa kluczowe: drgania poprzeczne, częstości rezonansowe, formy własne, przekładnie zębate

\section{Wprowadzenie}

Rozwój współczesnej techniki wymaga tworzenia urządzeń o przewidywalnej trwałości i niezawodności działania. Dotyczy to w szczególności układów produkowanych na potrzeby przemysłu lotniczego, farmaceutycznego, medycznego oraz biomedycznego. Jednym z istotnych czynników mogących zakłócić prawidłową pracę urządzeń jest możliwość pojawienia się drgań ich poszczególnych elementów bądź zespołów [6]. Z tego względu korzystnie jest na etapie projektowania wykonać badania modelowe, pozwalające ograniczyć skutki drgań. Obserwowany rozwój systemów obliczeniowych opartych na metodzie elemen-

\footnotetext{
1 Autor do korespondencji/corresponding author: Stanisław Noga, Politechnika Rzeszowska, al. Powstańców Warszawy 12, 35-959 Rzeszów, tel.: 178651639, e-mail: noga@prz.edu.pl

2 Tadeusz Markowski, Politechnika Rzeszowska, e-mail: tmarkow@prz.edu.pl
} 
tów skończonych (MES) pozwala analizować drgania układów o znacznym stopniu złożoności konstrukcyjnej. W pracy [4] omówiono badania symulacyjno-eksperymentalne (z uwzględnieniem MES) dotyczące drgań własnych stoiska do badań zmęczeniowych kół zębatych w układzie mocy krążącej. W publikacjach [1, 2, 6-10] analizowano drgania poprzeczne kół zębatych, modelowanych płytami kołowo-symetrycznymi, stosując MES oraz komercyjne systemy obliczeniowe. W monografii [6] omówiono różne przypadki drgań układów kołowo-symetrycznych, z uwzględnieniem rozwiązań analitycznych, numerycznych i doświadczalnych. W pracach $[3,11]$ dyskutowano zagadnienia drgań własnych przekładni planetarnych, z zastosowaniem zaproponowanych modeli dyskretnociągłych przekładni i wyznaczonych rozwiązań analitycznych. W niniejszej publikacji są rozważane drgania własne przekładni zębatej małej mocy. Zakres omawianych zagadnień obejmuje drgania poprzeczne kół zębatych przekładni wraz z wyznaczeniem prędkości wzbudzenia częstości własnych kół oraz drgania własne korpusu przekładni wraz z analizą naprężeń dla dopuszczalnej wartości przyspieszeń. Artykuł jest kontynuacją prac autorów dotyczących analizy drgań przekładni zębatych [7-9].

\section{Analizowany obiekt}

Przedmiotem rozważań jest analiza drgań reduktora pompy hydraulicznej (rys. 1), stanowiącego istotne urządzenie pomocnicze stoiska hamownianego. Reduktor składa się z trzech współpracujących ze sobą kół zębatych (rys. 1), osadzonych na łożyskach wałeczkowych w gniazdach korpusu. Korpus jest konstrukcją dzieloną, składającą się z korpusu zasadniczego i pokrywy (rys. 2). Pokrywa jest przymocowana do korpusu zasadniczego śrubami (21 sztuk) skręconymi z zadanym momentem zaciskowym. Cały zespół jest przymocowany tuleją montażową do korpusu urządzenia współpracującego. Odbiór i przekazanie mocy odbywają się za pośrednictwem dodatkowych wałów środkowych, współpracujących z kołami przez połączenia wielowypustowe. Jak wspomniano wcześniej,

a)

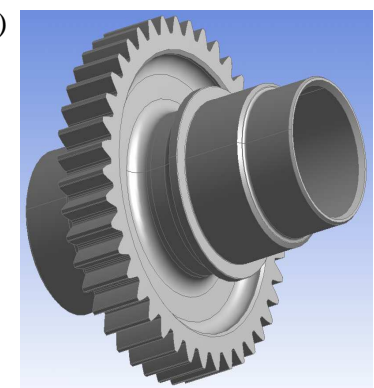

b)

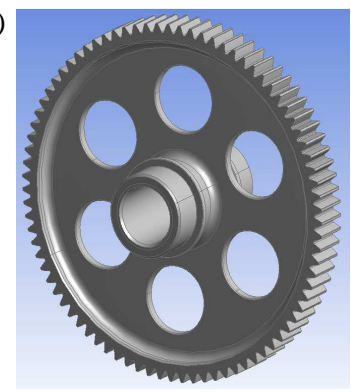

c)

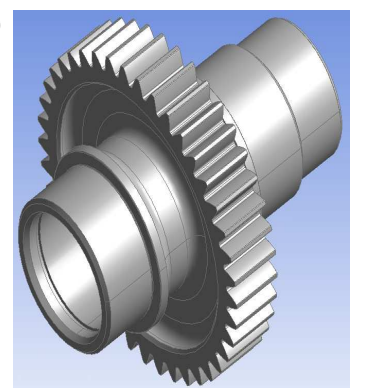

Rys. 1. Modele geometryczne kół zębatych: a) koło nr 1, b) koło nr 2, c) koło nr 3

Fig. 1. Geometrical models of the toothed gears: a) gear no. 1, b) gear no. 2, c) gear no. 3 

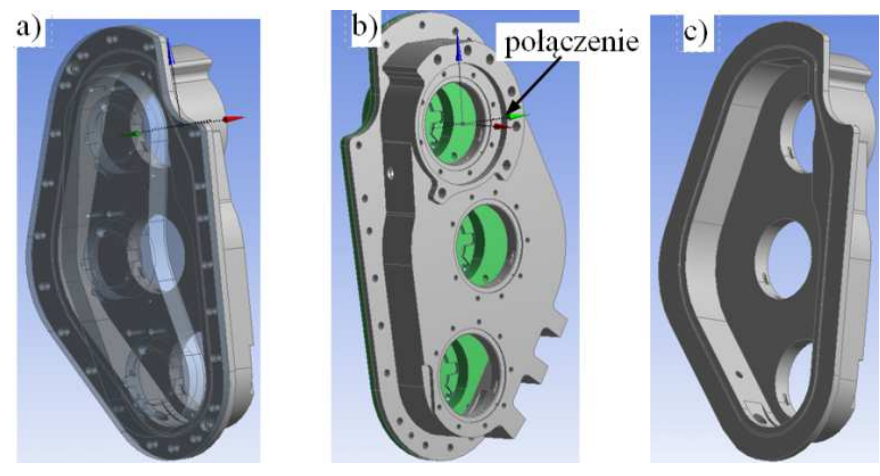

Rys. 2. Model geometryczny korpusu reduktora (a, b, c)

Fig. 2. A geometrical model of the body of reduction gear (a, b, c)

istotnymi elementami składowymi, z punktu widzenia rozważanych zagadnień, są koła zębate (rys. 1) oraz korpus zasadniczy i pokrywa (rys. 2). Koła zębate stanowią jednolite zespoły z wałami drążonymi. Dodatkowo koła nr 1 i 3 są przystosowane do odbioru i przekazywania ruchu obrotowego i mocy urządzeniom zewnętrznym przez połączenie wielowypustowe. Koła te charakteryzują się znacznym podobieństwem kształtowym (rys. 1a, c).

\section{Modele numeryczne rozważanych układów}

W pierwszym etapie rozważań opracowano modele numeryczne istotnych części składowych zespołu, czyli modele kół zębatych, korpusu zasadniczego i pokrywy. Proces modelowania i analizy prowadzono w środowisku obliczeniowym ANSYS. W celu uzyskania modeli charakteryzujących się optymalną liczbą elementów pominięto $\mathrm{w}$ modelach geometrycznych powierzchnie wynikające z zaokrągleń ostrych krawędzi. W przypadku kół dotyczy to głównie zaokrągleń głów i stóp zębów, wielowypustów oraz podcięć na czopach łożyskowych. W przypadku elementów korpusu pominięto także otwory pod śruby mocujące oraz geometrię kanałów smarujących. W procesie generowania siatki wymienionych części stosowano element bryłowy czworościenny (solid187), dziesięciowęzłowy, o trzech stopniach swobody w każdym węźle. Modele numeryczne kół nr 1 i 3 (rys. 3) zawierają odpowiednio 73028 elementów i 118848 węzłów. Model numeryczny koła nr 2 zawiera 49810 elementów oraz 89013 węzłów. W przypadku korpusu (rys. 4) model numeryczny całości (korpus zasadniczy i pokrywa) zawiera 137579 elementów oraz 212388 węzłów. W modelach kół zębatych warunki brzegowe przyłożono do węzłów. W każdym modelu węzłom leżącym na powierzchniach czopów łożyskowych odebrano stopnie swobody związane z przemieszczeniem promieniowym węzłów. Ponadto w modelach kół nr 1 i 3 węzłom leżącym na powierzchniach głów wielowypustów odebrano stopnie swobody związane z przemieszczeniem wzdłużnym oraz obrotem węzłów 
wokół osi obrotu wymieniowych kół. Współpracę pokrywy z korpusem zasadniczym zrealizowano przez tzw. sklejenie obu brył na powierzchni współpracy. Pozwoliło to wygenerować siatkę elementów skończonych obu ciał zgodną na tej powierzchni.
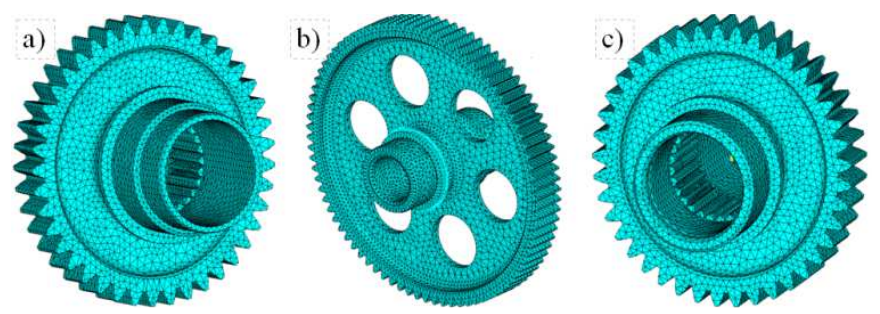

Rys. 3. Modele numeryczne kół zębatych: a) model koła nr 1, b) model koła nr 2, c) model koła nr 3

Fig. 3. FE models of the following gears: a) gear no. 1, b) gear no. 2 , c) gear no. 3
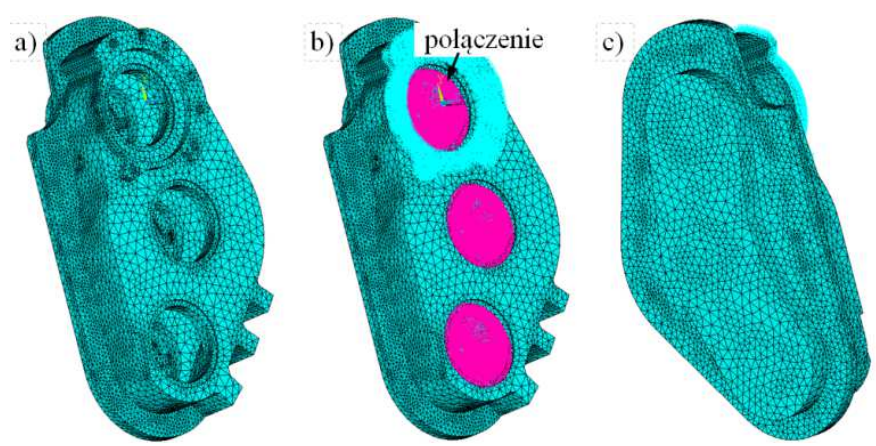

Rys. 4. Modele numeryczne korpusu reduktora: a) model pierwszy, b) model drugi, c) model trzeci

Fig. 4. FE models of the body of reduction gear: a) first model, b) second model, c) third model

Następnie węzłom leżącym na powierzchni współpracy reduktora z zewnętrznym urządzeniem (rys. 2, oznaczenie: połaczenie) odebrano stopień swobody związany z przemieszczeniem wzdłuż osi obrotu koła nr 1, stopień swobody związany z obrotem wokół tej osi oraz stopień swobody związany z przemieszczeniem promieniowym węzłów płaszczyzny współpracy względem tej samej osi. W obliczeniach numerycznych rozważono dwa modele numeryczne zespołu reduktora. $\mathrm{W}$ pierwszym modelu numerycznym uwzględniono geometrię i masy korpusu zasadniczego oraz pokrywy. W drugim modelu numerycznym układu uwzględniono dodatkowo masy kół zębatych reduktora. W tym przypadku mo- 
delu koła zębate zamodelowano jako tzw. sztywne obszary, zawierające punkty masowe, w których są umieszczone masy skupione kół [4].

\section{Analiza numeryczna}

Analizę drgań układu reduktora prowadzono dwuetapowo. W pierwszej kolejności wyznaczono częstości własne drgań poprzecznych kół zębatych z uwzględnieniem efektu wirowania. W dalszej kolejności analizowano drgania własne korpusu reduktora. W przypadku kół zębatych proces obliczeniowy wykonano w dwóch krokach obliczeniowych. W pierwszym kroku, związanym $\mathrm{z}$ analizą statyczną, wyznaczono rozkład naprężeń wynikający z rotacji. Następnie uzyskany rozkład uwzględniono w drugim kroku obliczeniowym, związanym $\mathrm{z}$ analizą modalną. Zgodnie ze standardami przyjętymi w teorii płyt kołowych i pierścieniowych, poszczególne częstości własne oznaczono przez $\omega_{m n}$, gdzie $m$ oznacza liczbę okręgów węzłowych, a $n$ odnosi się do liczby średnic węzłowych. $\mathrm{Na}$ podstawie prowadzonej analizy opracowano wykresy Campbella dla rozpatrywanych kół zębatych. Ze względu na realne niebezpieczeństwo pojawienia się drgań poprzecznych kół najbardziej niebezpieczna jest częstotliwość wymuszająca drgania poprzeczne od zazębienia [6]. Wyróżnia się tu tzw. częstotliwość wymuszenia podstawową od zazębienia (pierwsza harmoniczna), wyznaczaną z zależności [1, 6-8]:

$$
k_{1}=\left(n_{0} z\right) / 60
$$

oraz podwójną częstotliwość od zazębienia (druga harmoniczna), którą wyznacza się ze wzoru [1, 6-8]:

$$
k_{2}=2\left(n_{0} z\right) / 60
$$

W podanych zależnościach $n_{0}$ [obr./min] jest prędkością obrotową koła, a $z$ - liczbą zębów w kole. Zjawisko rezonansu może się pojawić w przypadku, gdy któraś z częstotliwości wymuszających ((1) lub (2)) zrówna się co do wartości z którąś z częstotliwości drgań własnych koła przy zmianie prędkości obrotowej. Szczególnie istotna jest możliwość wzbudzenia drgań od częstotliwości (1). W przypadku wystąpienia takiego faktu oblicza się dodatkowo częstotliwość wymuszającą od zazębienia z zależności [1, 6-8]:

$$
k_{1}^{*}=\left(n_{0} z \pm n\right) / 60
$$

gdzie, jak wcześniej wspomniano, $n$ jest liczbą średnic węzłowych. Prosta (1) w takim przypadku jest rozumiana jako nominalna podstawowa częstotliwość wymuszająca od zazębienia. W tabeli 1 podano dane techniczne oraz zakres operacyjny prędkości obrotowych analizowanych kół. 
Tabela 1. Dane techniczne i eksploatacyjne kół zębatych

Table 1. Technical and operational data for toothed gears

\begin{tabular}{|c|c|c|c|c|c|c|c|c|}
\hline Nr koła & Masa $[\mathrm{kg}]$ & $z$ & $\begin{array}{c}n_{1} \\
{[\text { obr./min }]}\end{array}$ & $\begin{array}{c}n_{2} \\
{[\text { obr./min }]}\end{array}$ & Moduł $[\mathrm{mm}]$ & $v$ & $\begin{array}{c}E \\
{[\mathrm{~Pa}]}\end{array}$ & $\begin{array}{c}\rho \\
{\left[\mathrm{kg} / \mathrm{m}^{3}\right]}\end{array}$ \\
\hline 1 & 1,29 & 41 & 3400 & 6500 & \multirow{2}{*}{2,5} & \multirow{2}{*}{0,3} & $2,06 \cdot 10^{11}$ & $7,85 \cdot 10^{3}$ \\
\hline 2 & 2,75 & 83 & 168 & 3211 & & & \\
\hline 3 & 1,29 & 41 & 3400 & 6500 & & & \\
\hline
\end{tabular}

W tabeli $1 v$ jest współczynnikiem Poissona, $E$ to moduł Younga, $\rho$-gęstość materiału, obroty $n_{1}$ i $n_{2}$ określają przedział wartości prędkości obrotowych, jakie mogą przyjmować koła w czasie pracy (tzw. zakres operacyjny). Dla omawianych kół obliczenia numeryczne ograniczono do wyznaczenia częstości własnych mniejszych lub równych $\omega_{16}$. Obliczenia wykonano przy założeniu, że koła obracają się z prędkościami obrotowymi z zakresu od 0 do $n_{2}$ (tab. 1 ). W celu uwzględnienia efektu wirowania, w procesie obliczeniowym zwiększano prędkości kątowe kół nr 1 i 3 o 1150 obr./min, a koła nr 2 o 860 obr./min, co dało siedem wariantów wyników dla kół nr 1 i 3 (częstości własne i odpowiadające im formy własne) oraz pięć dla koła nr 2, które należało zinterpretować. Otrzymane wyniki obliczeń wykorzystano do opracowania wykresów Campbella dla poszczególnych kół. Opis sposobu tworzenia wykresu Campbella można znaleźć między innymi w pracach $[1,6]$. Koła nr 1 i 3 charakteryzują się znacznym podobieństwem konstrukcyjnym. Występuje też znaczna zbieżność wyników obliczeń dla wymienionych kół. $\mathrm{Z}$ tego względu prezentowane będą wyniki obliczeń odnoszące się do kół nr 1 i 2 . W tabeli 2 podano wartości częstości drgań własnych koła nr 1 wyznaczone przy zadanych prędkościach obrotowych. W tabeli 3 podano wyniki obliczeń odnoszących się do koła nr 2. Otrzymane rozwiązania przedstawiono w kolejności występowania. Podczas analizy otrzymanych rezultatów zauważa się nieznaczny wpływ prędkości obrotowej na wzrost wartości poszczególnych częstości drgań własnych omawianych kół (nieznaczny wzrost sztywności giętej kół). Ponadto w przypadku koła nr 2 obserwuje się rozdzielenie wartości częstości $\omega_{13}, \omega_{23}$ i $\omega_{16}$. Jest to spowodowane występowaniem otworów przelotowych w tarczy koła. Szerszą dyskusję tego zagadnienia można znaleźć w pracach $[1,6,10]$. W dalszej kolejności prezentowane w tab. 2 i 3 wyniki wykorzystano do opracowania wykresów Campbella dla omawianych kół zębatych. Wykresy te posłużyły do wyznaczenia prędkości wzbudzenia poszczególnych częstości drgań własnych analizowanych kół. Na rysunku 5 pokazano wykres Campbella z zakresu częstotliwości 4600-5600 Hz odnoszący się do koła $\mathrm{nr} 1$. Z analizy wykresu zauważa się, że może wystąpić rezonans drgań od podwójnej częstotliwości wymuszającej od zazębienia (2), w zakresie operacyjnym koła (punkty przecięcia prostej (2) z krzywymi odnoszącymi się częstości drgań własnych). Linie pionowe $n k w_{1}, n k w_{2}, n k w_{3}$ na wykresie Campbella (rys. 5) odnoszą się do prędkości wzbudzenia częstości $\omega_{10}, \omega_{11}$ i $\omega_{12}$. W tabeli 4 zamieszczono wartości prędkości 
wzbudzenia wymienionych częstości własnych koła. Na rysunku 6 zilustrowano wykres Campbella z zakresu częstotliwości 2000-3500 Hz odnoszący się do koła nr 2. W tym przypadku zauważa się, że może wystąpić rezonans od częstości wymuszającej od zazębienia (1) z częstością $\omega_{13} \mathrm{~W}$ zakresie operacyjnym koła. Konieczne było więc dodatkowe wyznaczenie prostych (3). Linie $n w_{2}$ i $n w_{3}$ odnoszą się do nominalnych prędkości wzbudzenia częstości $\omega_{13}$, natomiast linie $n w_{1}$ i $n w_{4}$ - do prędkości wzbudzenia pochodzących od częstotliwości wymuszającej (3). W tabeli 5 podano wartości wymienionych prędkości wzbudzenia częstości $\omega_{13}$.

Tabela 2. Wpływ prędkości obrotowej na wartości częstości własnych (koło nr 1)

Table 2. The impact of the rotational speed on the natural frequency values (gear no. 1)

\begin{tabular}{|c|c|c|c|c|c|c|c|c|c|c|}
\hline \multirow{2}{*}{$\begin{array}{c}\text { Prędkość } \\
\text { obrotowa } \\
\text { [obr./min] }\end{array}$} & \multicolumn{10}{|c|}{ Częstotliwości własne $[\mathrm{Hz}]$} \\
\cline { 2 - 13 } & $\omega_{11}$ & $\omega_{12}$ & $\omega_{10}$ & $\omega_{13}$ & $\omega_{14}$ & $\omega_{20}$ & $\omega_{21}$ & $\omega_{15}$ & $\omega_{22}$ & $\omega_{16}$ \\
\hline 0 & 4726 & 5347 & 5430 & 10111 & 16821 & 21037 & 24025 & 24199 & 28128 & 31731 \\
\hline 1146 & 4726 & 5347 & 5430 & 10111 & 16822 & 21037 & 24025 & 24199 & 28128 & 31731 \\
\hline 2292 & 4727 & 5347 & 5430 & 10111 & 16822 & 21037 & 24025 & 24199 & 28128 & 31731 \\
\hline 3400 & 4727 & 5348 & 5430 & 10112 & 16822 & 21037 & 24026 & 24199 & 28129 & 31732 \\
\hline 4584 & 4727 & 5348 & 5431 & 10112 & 16822 & 21037 & 24026 & 24200 & 28129 & 31733 \\
\hline 5730 & 4728 & 5349 & 5431 & 10113 & 16823 & 21037 & 24026 & 24200 & 28129 & 31733 \\
\hline 6500 & 4728 & 5350 & 5431 & 10113 & 16823 & 21038 & 24027 & 24200 & 28130 & 31734 \\
\hline
\end{tabular}

Tabela 3. Wpływ prędkości obrotowej na wartości częstości własnych (koło nr 2)

Table 3. The impact of the rotational speed on the natural frequency values (gear no. 2)

\begin{tabular}{|c|c|c|c|c|c|c|c|c|c|c|c|c|c|}
\hline \multirow{2}{*}{$\begin{array}{c}\text { Pręd. } \\
\text { obrot. } \\
\text { [obr./min] }\end{array}$} & \multicolumn{13}{|c|}{ Częstotliwości własne [Hz] } \\
\hline & $\omega_{11}$ & $\omega_{10}$ & $\omega_{12}$ & $\omega_{13}$ & $\omega_{20}$ & $\omega_{21}$ & $\omega_{14}$ & $\omega_{22}$ & $\omega_{23}$ & $\omega_{15}$ & $\omega_{24}$ & $\omega_{30}$ & $\omega_{16}$ \\
\hline 0 & 443,2 & 626,2 & 978,9 & $\begin{array}{l}2706 \\
2741\end{array}$ & 4782 & 5045 & 5107 & 5811 & $\begin{array}{l}6402 \\
8811\end{array}$ & 7994 & 9594 & 10347 & $\begin{array}{l}11134 \\
11186\end{array}$ \\
\hline 859 & 443,5 & 626,3 & 979,2 & $\begin{array}{l}2706 \\
2741\end{array}$ & 4783 & 5045 & 5107 & 5811 & $\begin{array}{l}6402 \\
8811\end{array}$ & 7994 & 9594 & 10347 & $\begin{array}{l}11134 \\
11186\end{array}$ \\
\hline 1680 & 444,3 & 626,6 & 980,0 & $\begin{array}{l}2707 \\
2742\end{array}$ & 4783 & 5046 & 5108 & 5812 & $\begin{array}{l}6403 \\
8812\end{array}$ & 7994 & 9595 & 10348 & $\begin{array}{l}11134 \\
11187\end{array}$ \\
\hline 2578 & 445,8 & 627,3 & 981,5 & $\begin{array}{l}2708 \\
2743\end{array}$ & 4784 & 5047 & 5109 & 5813 & $\begin{array}{l}6405 \\
8813\end{array}$ & 7995 & 9596 & 10349 & $\begin{array}{l}11135 \\
11187\end{array}$ \\
\hline 3211 & 447,2 & 627,8 & 983,0 & $\begin{array}{l}2709 \\
2744\end{array}$ & 4786 & 5048 & 5109 & 5815 & $\begin{array}{l}6406 \\
8814\end{array}$ & 7996 & 9597 & 10350 & $\begin{array}{l}11136 \\
11188\end{array}$ \\
\hline
\end{tabular}

Dalszy etap badań odnosił się do analizy drgań własnych korpusu reduktora. Jak wspomniano wcześniej, rozważano przypadek, w którym uwzględniono tylko masę i geometrię korpusu oraz przypadek, w którym dodatkowo uwzględniono masy kół reduktora oraz ich położenie. Korpus jest wykonany ze stopu aluminium o następujących właściwościach mechanicznych: $\boldsymbol{E}=7,25 \cdot 10^{10} \mathrm{~Pa}, \boldsymbol{v}=0,33$, 


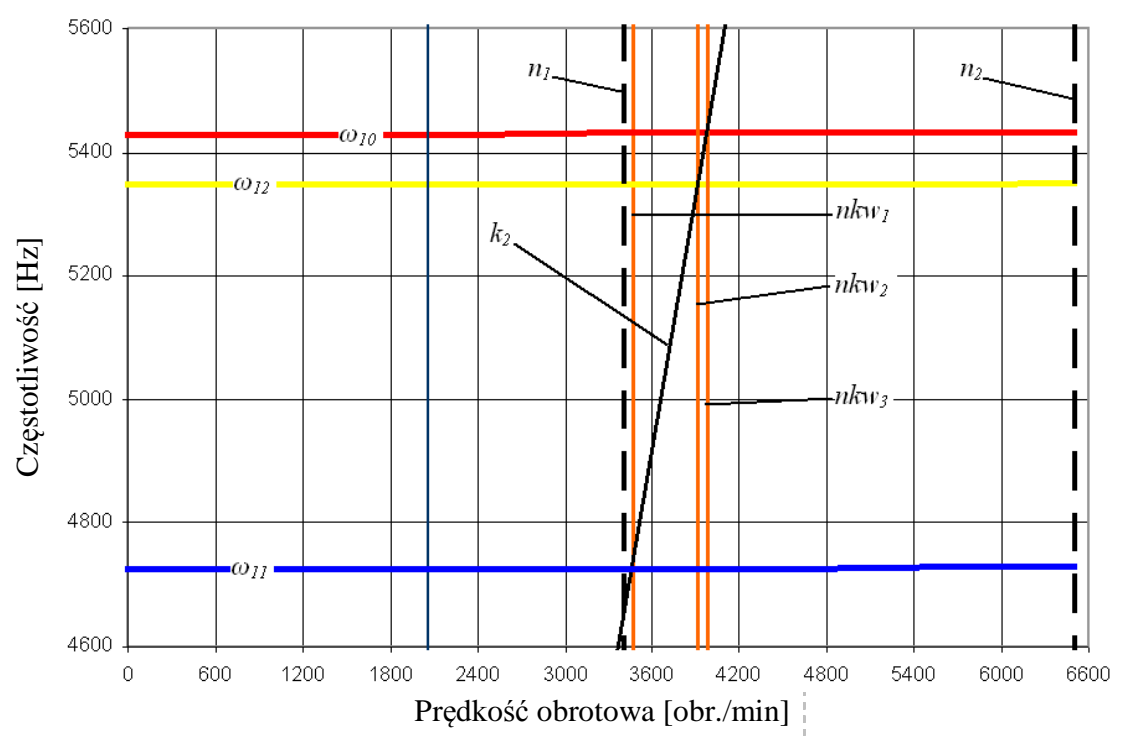

Rys. 5. Wykres Campbella dla koła nr 1

Fig. 5. The Campbell diagram for the gear no. 1

Tabela 4. Wartości prędkości wzbudzenia częstości własnych koła nr 1

Table 4. Values of the excitation speed of natural frequencies of gear no. 1

\begin{tabular}{|c|c|c|c|}
\hline \multirow{2}{*}{$\begin{array}{c}\text { Częstotliwość } \\
\text { wymuszająca }\end{array}$} & \multicolumn{3}{|c|}{ Prędkość wzbudzenia [obr./min] } \\
\cline { 2 - 4 } & $n k w 1$ & $n k w 2$ & $n k w 3$ \\
\cline { 2 - 4 } & 3460 & 3914 & 3975 \\
\hline$k_{2}$ & $\omega_{11}$ & $\omega_{12}$ & $\omega_{10}$ \\
\hline
\end{tabular}

Tabela 5. Wartości prędkości wzbudzenia częstości własnych koła nr 2

Table 5. Values of the excitation speed of natural frequencies of gear no. 2

\begin{tabular}{|c|c|c|c|c|}
\hline \multirow{2}{*}{$\begin{array}{c}\text { Częstotliwość } \\
\text { wymuszająca }\end{array}$} & \multicolumn{4}{|c|}{ Prędkość wzbudzenia [obr./min] } \\
\cline { 2 - 5 } & $n w_{1}$ & $n w_{2}$ & $n w_{3}$ & $n w_{4}$ \\
\cline { 2 - 5 } & 1889 & 1959 & 1984 & 2056 \\
\hline$k_{1}$ & & $\omega_{13}$ & $\omega_{13}$ & \\
\hline$k_{1}{ }^{*}$ & $\omega_{13}$ & & & $\omega_{13}$ \\
\hline
\end{tabular}

$\rho=2,79 \cdot 10^{3} \mathrm{~kg} / \mathrm{m}^{3}$. Oszacowana masa korpusu wynosi $14,7 \mathrm{~kg}$. Masy poszczególnych kół przyjęto zgodnie z tab. 1. Obliczenia numeryczne prowadzono z zastosowaniem omówionych wcześniej modeli numerycznych. W obu przypadkach modeli wyznaczono dziesięć pierwszych częstości własnych i odpowiadających im postaci drgań własnych. Wyniki obliczeń zamieszczono w tab. 6. 


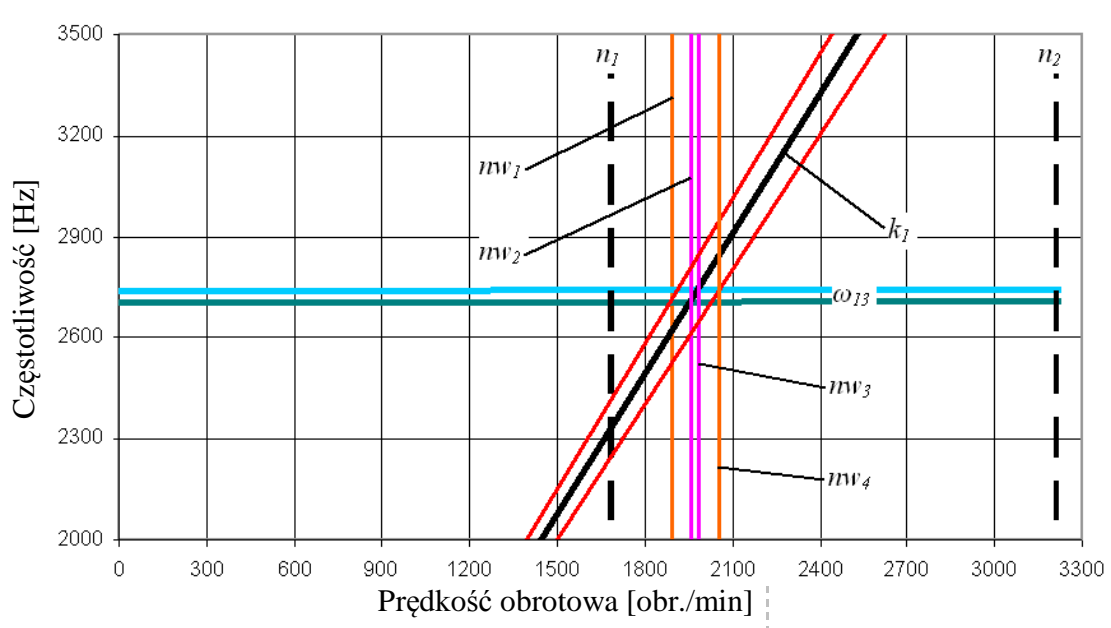

Rys. 6. Wykres Campbella dla koła nr 2

Fig. 6. The Campbell diagram of the gear no. 2

Na rysunku 7 pokazano dwie pierwsze postacie wygenerowane z wykorzystaniem opracowanych modeli. Analizując otrzymane wyniki, zauważa się podobieństwo kształtowe odpowiadających sobie w kolejności form własnych otrzymanych z pierwszego i drugiego modelu numerycznego. Zauważa się (tab. 6) znacznie wyższe wartości częstości własnych uzyskanych z drugiego modelu numerycznego (pomimo większej masy) w porównaniu z rezultatami otrzymanymi z pierwszego modelu. Zespoły ruchome reduktora pracują w zakresie prędkości obrotowej 1679-6500 obr./min, co w przeliczeniu na liczbę cykli wynosi 28-108 Hz. W zakresie tym mieszczą się prędkości obrotowe wzbudzenia częstości własnej $\omega_{13}$ koła nr 2. Wszystkie częstości drgań własnych korpusu (tab. 6) przyjmują wartości powyżej przedziału pracy zespołów ruchomych analizowanego urządzenia.

Tabela 6. Częstotliwości i postacie drgań własnych reduktora

Table 6. Natural frequencies and mode shapes of the free vibrations of the reduction gear

\begin{tabular}{|c|c|c|c|c|c|c|c|c|c|c|}
\hline \multicolumn{10}{|c|}{ Pierwszy model numeryczny } \\
\hline Nr postaci & P1 & P2 & P3 & P4 & P5 & P6 & P7 & P8 & P9 & P10 \\
\hline $\begin{array}{c}\text { Wartość częstotliwości } \\
\text { własnej } \omega^{p}[\mathrm{~Hz}]\end{array}$ & 419 & 596 & 1153 & 1750 & 1864 & 2081 & 2265 & 2807 & 2996 & 3113 \\
\hline \multicolumn{10}{|c|}{ Drugi model numeryczny } \\
\hline Nr postaci & D1 & D2 & D3 & D4 & D5 & D6 & D7 & D8 & D9 & D10 \\
\hline $\begin{array}{c}\text { Wartość częstotliwości } \\
\text { własnej } \omega^{p}[\mathrm{~Hz}]\end{array}$ & 679 & 830 & 1601 & 2291 & 2997 & 3115 & 3701 & 3967 & 4757 & 4969 \\
\hline
\end{tabular}


W kolejnym kroku obliczeniowym wyznaczono poziom naprężeń dla dopuszczalnej wartości przyspieszeń. Dla przypadku pracy reduktora (stoisko stacjonarne) przyjmuje się przyspieszenie dopuszczalne równe $2 g$, gdzie $g=9,81$ $\mathrm{m} / \mathrm{s}^{2}$. Dla wyznaczonych częstości własnych w pierwszej kolejności oblicza się tzw. przyspieszenie względne $p_{0} \mathrm{z}$ zależności $[7,8]$ :

$$
p_{0}=b \omega^{2}
$$

gdzie $b$ jest maksymalnym przemieszczeniem względnym dla danej postaci, a $\omega$ - częstością własną odnoszącą się do danej postaci. Następnie jest wyznaczany współczynnik $k_{w}$ ze wzoru [7, 8]:

$$
k_{w}=p_{0} /(2 g)
$$

a)

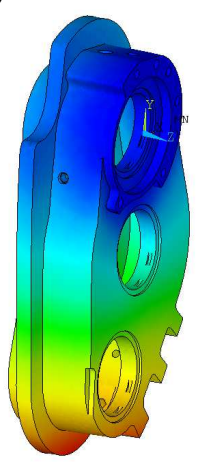

b)

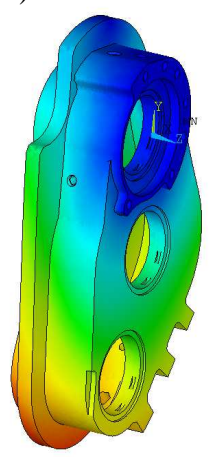

c)

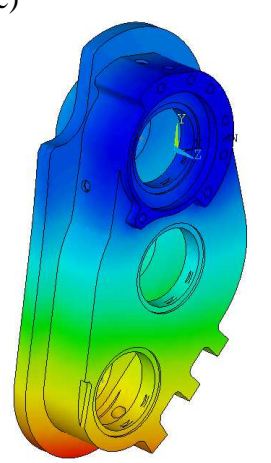

d)

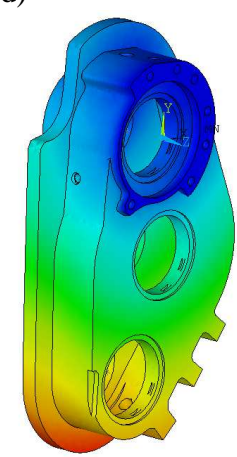

Rys. 7. Postacie drgań własnych korpusu: (a) P1, (b) P2, (c) D1, (d) D2

Fig. 7. The free vibration modes of the body: (a) P1, (b) P2, (c) D1, (d) D2

Dzieląc przez $k_{w}$ maksymalną wartość naprężeń zredukowanych względnych (wg hipotezy H-M-H) wyznaczanych dla danej częstości własnej, otrzymuje się tzw. maksymalną wartość naprężeń dla dopuszczalnej wartości przyspieszenia. Wielkość tę porównuje się z graniczną wytrzymałością zmęczeniową materiału, z którego jest wykonany korpus. W tabeli 7 podano, wyznaczone dla poszczególnych częstości własnych, maksymalne wartości naprężeń dla dopuszczalnej wartości przyspieszenia. Analizując otrzymane rezultaty, zauważa się nieco niższe wartości naprężeń dla dopuszczalnej wartości przyspieszenia w odniesieniu do drugiego modelu numerycznego układu. Dla każdej częstości własnej (tab. 7) maksymalna wartość naprężeń dla dopuszczalnej wartości przyspieszenia jest niższa od granicznej wytrzymałości zmęczeniowej materiału korpusu, której szacunkowa wartość przy liczbie $10^{8}$ cykli wynosi co najmniej 5,5·107 $\mathrm{Pa}$ [5]. 
Tabela 7. Poziom naprężeń dla dopuszczalnego przyspieszenia

Table 7. Stress level for the permissible acceleration

\begin{tabular}{|c|c|c|c|c|c|c|c|}
\hline \multicolumn{4}{|c|}{ Pierwszy model numeryczny } & \multicolumn{4}{|c|}{ Drugi model numeryczny } \\
\hline $\begin{array}{l}\mathrm{nr} \\
\text { formy }\end{array}$ & $\begin{array}{c}\text { przemiesz- } \\
\text { czenia } \\
\text { względem } \\
b \\
{[\mathrm{~m}]}\end{array}$ & $\begin{array}{c}\text { naprężenia } \\
\text { zredukowane } \\
\text { względne } \\
\text { (wg H-M-H) } \\
\text { [Pa] }\end{array}$ & $\begin{array}{c}\text { maks. poziom } \\
\text { naprężeń dla } \\
\text { dop. wartości } \\
\text { przyspieszeń } \\
\text { [Pa] }\end{array}$ & \begin{tabular}{|c|}
$\mathrm{nr}$ \\
formy
\end{tabular} & $\begin{array}{c}\text { przemiesz- } \\
\text { czenia } \\
\text { względem } \\
b \\
{[\mathrm{~m}]} \\
\end{array}$ & $\begin{array}{c}\text { naprężenia } \\
\text { zredukowane } \\
\text { względne } \\
\text { (wg H-M-H) } \\
\text { [Pa] }\end{array}$ & $\begin{array}{c}\text { maks. poziom } \\
\text { naprężeń dla } \\
\text { dop. wartości } \\
\text { przyspieszeń } \\
\text { [Pa] }\end{array}$ \\
\hline P1 & 0,5807 & $2,95 \cdot 10^{11}$ & $1,44 \cdot 10^{6}$ & D1 & 0,5308 & $4,20 \cdot 10^{11}$ & $8,53 \cdot 10^{5}$ \\
\hline $\mathrm{P} 2$ & 0,4864 & $1,93 \cdot 10^{11}$ & $5,56 \cdot 10^{5}$ & D2 & 0,4850 & $4,29 \cdot 10^{11}$ & $6,39 \cdot 10^{5}$ \\
\hline P3 & 0,6479 & $3,78 \cdot 10^{11}$ & $2,18 \cdot 10^{5}$ & D3 & 0,7389 & $5,02 \cdot 10^{11}$ & $1,32 \cdot 10^{5}$ \\
\hline $\mathrm{P} 4$ & 0,5406 & $5,72 \cdot 10^{11}$ & $1,72 \cdot 10^{5}$ & D4 & 0,3597 & $8,43 \cdot 10^{11}$ & $2,22 \cdot 10^{5}$ \\
\hline P5 & 0,5791 & $5,10 \cdot 10^{11}$ & $1,26 \cdot 10^{5}$ & D5 & 0,6402 & $1,32 \cdot 10^{12}$ & $1,14 \cdot 10^{5}$ \\
\hline P6 & 0,5099 & $6,33 \cdot 10^{11}$ & $1,42 \cdot 10^{5}$ & D6 & 0,5046 & $1,17 \cdot 10^{12}$ & $1,19 \cdot 10^{5}$ \\
\hline $\mathrm{P} 7$ & 1,0980 & $8,86 \cdot 10^{11}$ & $7,82 \cdot 10^{5}$ & D7 & 1,5620 & $1,28 \cdot 10^{12}$ & $2,97 \cdot 10^{4}$ \\
\hline P8 & 0,9429 & $5,52 \cdot 10^{11}$ & $3,69 \cdot 10^{5}$ & D8 & 2,5880 & $1,84 \cdot 10^{12}$ & $2,25 \cdot 10^{4}$ \\
\hline $\mathrm{P9}$ & 0,6480 & $5,74 \cdot 10^{11}$ & $4,90 \cdot 10^{5}$ & D9 & 1,8410 & $1,31 \cdot 10^{12}$ & $1,56 \cdot 10^{4}$ \\
\hline P10 & 0,6799 & $8,59 \cdot 10^{11}$ & $6,48 \cdot 10^{5}$ & D10 & 0,8737 & $1,42 \cdot 10^{12}$ & $3,27 \cdot 10^{4}$ \\
\hline
\end{tabular}

\section{Uwagi i wnioski}

Projektowanie współczesnych urządzeń wymaga stosowania zaawansowanych technik obliczeniowych, co pozwala prowadzić analizy statyczne i dynamiczne złożonych układów technicznych na etapie projektowym. W pracy są rozważane zagadnienia drgań własnych przekładni zębatej małej mocy. W procesie analizy stosowano metodę elementów skończonych oraz komercyjne oprogramowanie ANSYS. Jak pokazano w pracy, wykres Campbella stanowi użyteczne narzędzie w analizie drgań wirujących układów, ze szczególnym uwzględnieniem kół zębatych. Z otrzymanych rezultatów wynika, że istnieje niebezpieczeństwo wzbudzenia częstości własnej $\omega_{13}$ koła $\mathrm{nr} 2 \mathrm{w}$ zakresie operacyjnym przez częstotliwość wymuszającą od zazębienia. Zauważa się także nieco niższe wartości naprężeń względnych dla dopuszczalnej wartości przyspieszenia w odniesieniu do wyników z drugiego modelu numerycznego. Prezentowane analizy, w szczególności dotyczące drgań korpusu, wymagają dalszych badań, z uwzględnieniem weryfikacji eksperymentalnej. Prezentowana metodyka może być pomocna inżynierom zajmującym się analizą drgań przekładni zębatych.

\section{Literatura}

[1] Bogacz R., Noga S.: Free transverse vibration analysis of a toothed gear, Arch. Applied Mech., 82 (2012) 1159-1168.

[2] Drago R.J., Brown F.W.: The analytical and experimental evaluation of resonant response in high-speed, lightweight, highly loaded gearing, ASME J. Mech. Design, 103 (1981) 346-356. 
[3] Kiracofe D.R., Parker R.G.: Structured vibration modes of general compound planetary gear systems, ASME J. Vibration Acoustics, 129 (2007) 1-16.

[4] Markowski T., Noga S., Rudy S.: Modelling and vibration analysis of some complex mechanical systems, [in:] Recent advances in vibrations, ed. N. Baddour, Intech Open Access Publisher, Rijeka 2011, pp. 143-168.

[5] Niezgodziński M., Niezgodziński T.: Wzory, wykresy i tablice wytrzymałościowe, WNT, Warszawa 2013.

[6] Noga S.: Analityczne i numeryczne zagadnienia drgań układów z symetrią kołową, OW PRz, Rzeszów 2015.

[7] Noga S., Markowski T.: Modelling and vibration analysis of a low-power transmission gear, Progressive technologies and materials, ed. J. Mucha, OW PRz, Rzeszow 2016, pp. 47-60.

[8] Noga S., Markowski T.: Vibration analysis of a low-power reduction gear, Strength Materials, 48 (2015) 507-514.

[9] Noga S., Markowski T.: Vibration analysis of the low-power transmission gear, [in:] Proc. Int. Sci. Conf. PRO-TECH-MA'2016, Bezmiechowa 2016, pp. 87-88.

[10] Noga S., Markowski T., Bogacz R.: Metoda oznaczania form własnych kół zębatych o złożonym kształcie, ZN Politechniki Śląskiej, Seria Transport, 89 (2015) 119-127.

[11] Wu X., Parker R.G.: Modal properties of planetary gears with an elastic continuum ring gear, ASME J. Applied Mechanics, 75 (2008) 031014-031014-12.

\section{FREE VIBRATION ANALYSIS OF A LOW-POWER GEAR}

\section{S u m m a r y}

This paper discusses the free vibrations of the low-power gear which is dedicated to cooperate with the hydraulic pump of the test rig. The finite element (FE) method and the commercial ANSYS software are employed. The vibration analysis of the discussed system is performed in two stages. Firstly the natural frequencies of the free transverse vibration of the gears are obtained with including the centrifugal effect. Next, on the basis of the elaborated Campbell diagrams, the excitation speeds for selected natural frequencies of the analyzed wheels are obtained. Then, the free vibrations of the reduction gear are analyzed and two computational cases are discussed. In the first computing case, only the mass and geometry of all parts of the body are taken into account. In the second case, the mass of the toothed gears is also included. Based on the elaborated FE models, the first ten natural frequencies and natural mode shapes of the reduction gear are obtained. Then, these results are used to estimate the stress level in the walls of the body for the permissible acceleration value. Presented investigation can be attractive for design engineers dealing with the dynamics of complex systems.

Keywords: transverse vibrations, resonance frequencies, normal modes, gears

DOI: $10.7862 / \mathrm{rm} .2017 .48$

Przestano do redakcji: 17.09 .2017

Przyjęto do druku: 18.10.2017 